\title{
Dimensi Pengawasan pada Tindak Lanjut Laporan Pengaduan Masyarakat kepada Komisi Kejaksaan dalam Tinjauan Hukum Progresif
}

\section{The Supervisory Dimensions in the Follow-Up of Public Complaint Reports \\ to The Commission of Prosecution of The Republic of Indonesia within the Progressive Legal Review}

\author{
R. Muhamad Ibnu Mazjah \\ Komisi Kejaksaan Republik Indonesia \\ Jl. Rambai No. 1 A, Kebayoran Baru, Jakarta Selatan \\ Email:komjak07@gmail.com \\ Naskah diterima: 7 Mei 2020 \\ Naskah direvisi: 28 September 2020 \\ Naskah diterbitkan: 1 November 2020
}

\begin{abstract}
Presidential Decree No. 18 of 2011 on the Prosecutors Commission of the Republic of Indonesia (PCRI) does not contain textual procedural law provisions regarding follow-up reports on public complaints. This raises a question of whether the PCRI has the authority to carry out direct examinations and investigations as part of its authority to follow up public complaints. Based on the provisions of Articles $4 a$ and $4 b$ of the Presidential Decree No. 18 of 2011, it is acknowledged that after PCRI received public complaints, PCRI has two options in exercising its authority, namely carrying out a direct follow-up or forwarding these public complaints to the Attorney General and have it followed-up by internal supervisors. However, the absence of written or textual provisions in the Presidential Decree No. 18 of 2011 regarding this matter has resulted in the interpretation that PCRI is not authorized to conduct direct examinations, inspections, and investigations. This encourages the author to interpret that the authority of the PCRI in carrying out the follow-up on public complaints is based on a progressive legal perspective. This writing uses a normative research method, which aims to obtain legal arguments about the dimensions of supervision as a follow-up to public complaint reports. This paper is expected to introduce a reasoned discussion of PCRI in carrying out the supervisory duties. At the end part of this paper, there are recommendations regarding the need for regulatory authority as reinforcement for PCRI in carrying out supervisory duties and its authority to impose sanctions in the event of non-compliance. At the operational level, it is necessary to have a common perception shared between PCRI and Prosecutors of the Republic of Indonesia to create synergy in carrying out supervisory duties.
\end{abstract}

Keywords: supervision; The Commission of Prosecution; progressive law; follow up; public complaint reports

\begin{abstract}
Abstrak
Perpres Nomor 18 Tahun 2011 tentang Komisi Kejaksaan RI (KKRI) tidak memuat secara tekstual ketentuan hukum acara tentang tindak lanjut laporan pengaduan masyarakat (lapdumas). Hal ini menimbulkan pertanyaan, apakah KKRI memiliki kewenangan melakukan pemeriksaan dan pengusutan secara langsung sebagai bagian dari kewenangan menindaklanjuti lapdumas. Berdasarkan ketentuan Pasal 4 a dan 4 b Perpres No. 18 Tahun 2011 dapat diketahui bahwa setelah KKRI menerima lapdumas, KKRI memiliki dua opsi kewenangan yakni menindaklanjuti secara langsung atau meneruskan lapdumas tersebut kepada Jaksa Agung untuk ditindaklanjuti pengawas internal. Namun, tidak adanya ketentuan tertulis di dalam Perpres No. 18 Tahun 2011, menimbulkan tafsir KKRI tidak berwenang melakukan pemeriksaan, pengusutan, penyelidikan secara langsung. Hal ini mendorong penulis untuk menafsirkan kewenangan KKRI dalam menindaklanjuti lapdumas berdasarkan perspektif hukum progresif. Penulisan ini menggunakan metode penelitian normatif, yang
\end{abstract}


bertujuan untuk mendapatkan argumentasi hukum tentang dimensi pengawasan sebagai tindak lanjut laporan pengaduan masyarakat. Tulisan ini diharapkan dapat berdaya guna dalam pengembanan tugas pengawasan oleh KKRI. Di bagian akhir, tertuang rekomendasi mengenai perlunya pengaturan kewenangan sebagai penguatan bagi KKRI dalam menjalankan tugas pengawasan serta kewenangan penjatuhan sanksi apabila terjadi ketidakpatuhan. Pada tataran operasional, diperlukan penyamaan persepsi antara KKRI dengan Kejaksaan RI agar tercipta sinergitas dalam menjalankan tugas pengawasan.

Kata kunci: pengawasan; Komisi Kejaksaan; hukum progresif; tindak lanjut; laporan pengaduan masyarakat

\section{Pendahuluan}

Peraturan Presiden Nomor 18 Tahun 2011 tentang Komisi Kejaksaan Republik (Perpres No. 18 Tahun 2011) mengatur tugas Komisi Kejaksaaan Republik Indonesia (KKRI) yang terdiri atas dua objek. Objek pertama berupa pengawasan, pemantauan, dan penilaian terhadap personel (individu) aparat kejaksaan, yaitu jaksa dan pegawai kejaksaan yang selanjutnya disebut dengan pegawai tata usaha. Adapun objek kedua berupa pemantauan dan penilaian terhadap kejaksaan sebagai institusi. Ruang lingkup tugas KKRI untuk pengawasan, pemantauan, dan penilaian personel meliputi aspek kinerja dan perilaku dalam melaksanakan tugas dan wewenang yang diatur di dalam peraturan perundang-undangan dan kode etik, serta perilaku di dalam maupun di luar tugas kedinasan. ${ }^{1}$

Adapun pemantauan dan penilaian terhadap institusi meliputi kondisi organisasi, tata kerja, kelengkapan sarana dan prasarana, serta sumber daya manusia di lingkungan kejaksaan. ${ }^{2}$ Aspek administratif lebih menonjol

Pasal 3 huruf a dan huruf b Peraturan Presiden Nomor 18 Tahun 2011 tentang Komisi Kejaksaan Republik Indonesia. Pasal 3 huruf c Peraturan Presiden Nomor 18 Tahun 2011 tentang Komisi Kejaksaan Republik Indonesia. pada tugas ini, sehingga berbeda dengan pengawasan terhadap personel. Titik berat pertanggungjawaban dalam aspek ini diemban oleh pejabat-pejabat struktural di kejaksaan sesuai dengan bidang tugasnya masing-masing. Namun, pengawasan terhadap aparat kejaksaan dari sisi kinerja dan perilaku memegang peranan penting, untuk mengontrol ruang terjadinya penyalahgunaan wewenang yang berkaitan dengan pelaksanaan tugas penegakan hukum.

Selain itu, pengawasan terhadap perilaku personel aparat kejaksaan di luar kedinasan dilakukan untuk menjaga kehormatan institusi dari perbuatan tercela serta mencegah kemungkinan terjadinya bias pada penggunaan kedudukan dan jabatan yang melekat pada diri masing-masing personel tersebut. Satu hal penting yang tidak boleh diabaikan, yaitu kewenangan KKRI dalam tugas pengawasan tidak melulu bersifat punishment, tetapi juga berwenang memberikan reward kepada para Jaksa dan pegawai tata usaha yang berprestasi. Keseimbangan dalam menjalankan tugas tersebut diharapkan akan membawa hasil yang objektif dalam setiap lini pengawasan. Ini akan berdampak pada keberadaan KKRI mampu menjadi faktor penunjang bagi peningkatan kualitas kinerja kejaksaan, sehingga sesuai dengan tujuan dibentuknya KKRI.

Seiring dengan tugas KKRI tersebut, Perpres No. 18 Tahun 2011 memberikan kewenangan kepada KKRI untuk menerima dan menindaklanjuti laporan dan/atau pengaduan masyarakat (Lapdumas). ${ }^{3}$ KKRI dalam menjalankan tugas dan wewenangnya ini dapat menyampaikan dan/atau memberikan rekomendasi kepada Jaksa Agung. Rekomendasi tersebut berupa rekomendasi usulan pemberian sanksi terhadap Jaksa dan/ atau pegawai Kejaksaan yang disampaikan kepada Jaksa Agung sesuai dengan pelanggaran yang dilakukan sebagaimana dimaksud dalam Peraturan Pemerintah Nomor 53 Tahun 2010 (PP No. 53 Tahun 2010) tentang Disiplin Pegawai Negeri Sipil, Kode Etik, dan/atau

Pasal 4 huruf a Peraturan Presiden Nomor 18 Tahun 2011 tentang Komisi Kejaksaan Republik Indonesia. 
peraturan perundang-undangan. ${ }^{4}$ Pengaturan mengenai penyampaian rekomendasi kepada Jaksa Agung terkait penjatuhan sanksi yang direkomendasikan mulai dari tingkat ringan, sedang hingga berat oleh kepada KKRI telah tertulis di dalam Perpres No. 18 Tahun 2011, tetapi tidak tampak adanya hukum acara sebagai sarana dalam menjalankan tugas dan kewenangan bagi lembaga ini.

Ketiadaan hukum acara untuk menindaklanjuti Lapdumas di dalam Perpres No. 18 Tahun 2011 menimbulkan pertanyaan tentang apa yang dimaksud dengan menindaklanjuti lapdumas. Hal ini disebabkan terminologi dari frasa menindaklanjuti masih bersifatumum, sertatidakadapenjelasantekstual mengenai frasa tersebut di dalam Perpres No. 18 Tahun 2011. Di dalam praktik, tidak adanya tafsir tentang makna dari menindaklanjuti lapdumas itu melahirkan asumsi bahwa KKRI tidak berwenang melakukan pemeriksaan dan pengusutan terhadap dugaan pelanggaran sebagai sebuah rangkaian kegiatan pengawasan dan sebagai suatu bentuk tindak lanjut terhadap suatu lapdumas yang disampaikan kepada KKRI. Asumsi tersebut diperkuat dengan adanya ketentuan dalam Perpres No. 18 Tahun 2011 mengenai pemeriksaan, yang sebatas pada pemeriksaan ulang, pemeriksaan tambahan, dan pengambilalihan pemeriksaan. ${ }^{5}$

Asumsi tersebut tentu tidak memiliki landasan hukum yang kuat serta bertolak belakang (contradictio in terminis) dengan aturan tentang kewenangan KKRI untuk memberikan rekomendasi. Dalam konteks ini, rekomendasi dimaksud adalah rekomendasi usulan pemberian sanksi terhadap Jaksa dan/atau pegawai Kejaksaan sesuai dengan pelanggaran yang dilakukannya. Sebuah rekomendasi yang

Pasal 9 huruf c Peraturan Presiden Nomor 18 Tahun 2011 tentang Komisi Kejaksaan Republik Indonesia.

Ketentuan tentang pemeriksaan ulang dan pemeriksaan tambahan tertulis di dalam Pasal 4 huruf d, sedangkan pengambilalihan pemeriksaan tertulis pada Pasal 4 huruf c Peraturan Presiden Nomor 18 Tahun 2011 tentang Komisi Kejaksaan Republik Indonesia. Nomenklatur pemeriksaan tersebut merupakan upaya pemeriksaan yang dilakukan oleh KKRI setelah pengawas internal kejaksaan melakukan pemeriksaan terlebih dahulu. objektif dan kredibel mutlak tidak mungkin dapat dikeluarkan, tanpa dilekati kewenangan untuk melakukan pemeriksaan, pengujian, dan penilaian. Berdasarkan hal itu, penafsiran yang jelas amat dibutuhkan bagi KKRI sebagai dasar pijakan KKRI dalam mengemban tugasnya, yang berkenaan dengan pengejewantahan wewenang sebagaimana diatur dalam Pasal 4 huruf a Perpres No. 18 Tahun 2011. Oleh karenanya, permasalahan hukum yang dikaji dalam penulisan ini, yaitu apa makna pengawasan pada tindak lanjut laporan pengaduan masyarakat yang disampaikan kepada KKRI ditinjau dari perspektif hukum progresif dan bagaimana penerapan hukum atas tugas dan wewenang KKRI dalam menindaklanjuti lapdumas yang disampaikan kepadanya.

Berdasarkan kedua permasalahan tersebut, penulisan ilmiah ini bertujuan untuk mendapatkan argumentasi hukum mengenai makna pengawasan pada tindak lanjut laporan pengaduan masyarakat yang disampaikan kepada KKRI ditinjau dari perspektif hukum progresif dan mendapatkan argumentasi hukum mengenai penerapan hukum atas tugas dan wewenang KKRI dalam menindaklanjuti lapdumas yang disampaikan kepadanya. Argumentasi hukum tersebut diharapkan dapat berdaya guna secara praktis untuk pengembanan tugas pengawasan oleh KKRI dan secara akademis dapat menjadi sumbangan pemikiran untuk perbaikan pengaturan tugas dan kewenangan KKRI.

Berkenaan dengan kebaruan dan orisinilitas dari penulisan ini, penulis mengajukan beberapa artikel yang membahas terkait tema Komisi Kejaksaan Republik Indonesia sebagai bahan perbandingan. Artikel tersebut ditulis oleh Choky R. Ramadhan dengan judul "Kedudukan, Tugas dan Kewenangan Komisi Kejaksaan”. Artikel tersebut memfokuskan pembahasan tentang posisi KKRI di dalam struktur ketatanegaraan berserta kewenangan yang dimilikinya. Adapun artikel yang diangkat oleh penulis berbeda dengan artikel tersebut, yang memiliki kebaruan serta lebih spesifik membahas tentang kewenangan KKRI di bidang 
pengawasan khususnya terkait kewenangan untuk menindaklanjuti pengaduan masyarakat.

Artikel berikutnya ditulis oleh Ajeng Triwahyuni dengan judul Strategi Penguatan Komisi Kejaksaan Dalam mendorong Pencegahan dan Pemberantasan Korupsi. Artikel ini membahas tentang strategi KKRI dalam mengemban tugas dan tanggungjawabnya selaku pengawas eksternal guna mendorong upaya-upaya pencegahan dan pemberantasan korupsi. Adapun artikel yang penulis sampaikan memiliki perbedaan dan kebaruan dengan materi pembahasan menyangkut kewenangan KKRI di bidang pengawasan khususnya terkait kewenangan untuk menindaklanjuti pengaduan masyarakat.

\section{Metode Penelitian}

llmu hukum memiliki karakteristik ilmu yang bersifat preskriptif dan terapan. ${ }^{6}$ Oleh karena itu, metode penelitian yang digunakan adalah penelitian normatif yang memiliki sifat perskriptif atau menggambarkan apa yang seharusnya ada. Adapun pendekatan yang digunakan ialah pendekatan undangundang (statute approach) dan pendekatan konseptual (conceptual approach). Pendekatan konseptual berangkat dari pandangan, konsep dan teori yang berkembang di dalam ilmu hukum yang meliputi aspek asas negara hukum dan asas negara demokrasi, sebagai ide dasar pengawasan yang melandasi pembentukan KKRI. Selain itu, penulis juga menggunakan perspektif teori hukum progresif sebagai salah satu teori dalam ilmu hukum untuk menguji validitas tugas pengawasan KKRI berdasarkan konsep yang ideal. Penulisan ini menggunakan alur deduktif yang berpangkal dari pengajuan premis mayor dan premis minor. Premis mayor yang diajukan berupa pemaparan tentang asas negara hukum dan asas negara demokrasi, serta prinsip keseimbangan serta saling kontrol antara lembaga negara di dalam menjalanakan pemerintahan (konsep tentang check and balance). Di samping itu, diuraikan pula ide

Peter Mahmud Marzuki, Penelitian Hukum, Jakarta: Prenadamedia, 2007, hal. 17. dan fungsi pengawasan serta pembentukan KKRI sebagai wujud dari penjabaran negara hukum dan negara demokrasi. Adapun premis minor diajukan untuk menganalisis ada atau tidaknya kesesuaian antara tugas pengawasan yang dilakukan KKRI dengan konsep, asas, dan pandangan atau doktrin-doktrin yang dipaparkan pada premis mayor sehingga dapat ditarik sebagai sebuah konklusi.

\section{Landasan Filosofi Checks and Balances sebagai Pilar Fungsi Pengawasan}

\section{A. Ide tentang Pengawasan dan Kedudukan KKRI}

Ide tentang pengawasan bermula dari adanya kewenangan yang sangat besar di dalam penyelenggaraan pemerintahan oleh pihak eksekutif, sehingga menimbulkan kecenderungan terjadinya penyimpangan. Untuk mengontrol kemungkinan terjadinya penyimpangan tersebut, pengawasan antarlembaga dalam bingkai sistem checks and balances dipandang sebagai langkah yang sudah semestinya. Prinsipcheck and balances merupakan prinsip ketatanegaraan yang menghendaki agar kekuasaan legislative, eksekutif, dan yudikatif sama-sama sederajat dan saling mengontrol satu sama lain?.

Checks and balances merupakan salah satu perwujudan dari asas negara hukum dan asas negara demokrasi. Adapun mengacu UndangUndang Dasar Negara Republik Indonesia Tahun 1945 (UUD NRI Tahun 1945) sebagaimana tertuang dalam Pasal 1 ayat (2) dan ayat (3), prinsip check and balance masih dianut namun tidak secara total. Asas negara hukum dan asas negara demokrasi tidak dapat dilepaskan dari topik penulisan ini, karena fungsi pengawasan inklusif kedudukan KKRI sebagai lembaga negara merupakan bagian yang tidak terpisahkan dari kedua asas tersebut.

Ketika membahas tentang negara hukum, sistem ketatanegaraan menjadi padanannya. Menurut Didi Nazmi Yunas, pembicaraan

Jimly Asshiddiqie dalam Sunarto, "Prinsip Check And Balance Dalam Sistem Ketatanegaraan Indonesia", Jurnal Masalah-Masalah Hukum, Vol. 45, No. 2, 2016, hal. 159. 
mengenai konsepsi dari negara hukum jelas tidak terlepas dari konstitusi atau sistem ketatanegaraan RI. $^{8}$ Didi Nazmi Yunas menjelaskan sistem ketatanegaraan suatu negara pada umumnya dapat dilihat dalam konstitusi atau undang-undang dasarnya. Pengertian konstitusi paling sedikit memiliki dua arti, yaitu pertama, kumpulan peraturan yang membentuk, mengatur, atau memerintah negara dan kedua, campuran antara hukum tertulis dan yang tidak tertulis. ${ }^{9}$

Adapun padanannya, yakni negara hukum. Prinsip negara hukum pada dasarnya berdiri di atas landasan ide negara hukum yang telah lama dikembangkan oleh para filsuf dari zaman Yunani Kuno. Plato dalam the Republic berpendapat bahwa mungkin mewujudkan negara ideal untuk mencapai kebaikan yang berintikan kebaikan ${ }^{10}$. Untuk itu, kekuasaan harus dipegang oleh seorang filosof. ${ }^{11}$ Aristoteles memiliki pandangan yang sama dengan Plato. Tujuan negara hukum menurut Plato adalah untuk mencapai kehidupan yang paling baik (the best life possible) yang dapat dicapai dengan supremasi hukum. Hukum adalah wujud kebijaksanaan kolektif warga negara (collective wisdom), sehingga peran warga negara diperlukan dalam pembentukannya. ${ }^{12}$

Menurut Aristoteles, negara yang baik adalah negara yang diperintah dengan konstitusi dan berkedaulatan hukum. Berkenaan dengan itu, ada tiga unsur dari pemerintahan yang berkonstitusi, yaitu pertama, pemerintahan dilaksanakan untuk kepentingan umum; kedua, pemerintahan dilaksanakan menurut hukum yang berdasarkan pada ketentuan-ketentuan umum, bukan hukum yang dibuat sewenangwenang yang mengesampingkan konvensi dan konstitusi; dan ketiga, pemerintahan berkonstitusi berarti pemerintahan yang

\footnotetext{
8 Marwan Effendy, Kejaksaan Posisi dan Fungsinya Dari Perspektif Hukum, Jakarta: Gramedia Pustaka Utama, 2005, hal. 11

9 Ibid, hal. 12.

10 Jimly Asshiddiqie, Hukum Tata Negara dan Pilar-Pilar Demokrasi, Jakarta: Konstitusi Pers, 2004 hal. 147.

$11 \quad$ Ibid.

12 Ibid
}

dilaksanakan atas kehendak rakyat, bukan berupa paksaan-tekanan yang dilaksanakan pemerintahan despotik. ${ }^{13}$

Ada dua isu pokok yang senantiasa menjadi inspirasi perkembangan asas negara hukum adalah pembatasan kekuasaan dan perlindungan hak asasi manusia. ${ }^{14}$ Pembatasan kekuasaan dilakukan dengan hukum yang kemudian menjadi dasar paham konstitusionalisme modern. ${ }^{15}$ Perlindungan hak asasi manusia (HAM) dapat dimaknai sebagai adanya perlindungan konstitusional terhadap HAM dengan jaminan hukum bagi tuntutan penegakannya melalui proses yang adil. Terbentuknya negara dan penyelenggaraan kekuasaan negara tidak boleh mengurangi arti dan makna kebebasan dasar dan HAM. Jika di suatu negara HAM terabaikan atau pelanggaran HAM tidak dapat diatasi secara adil, maka negara itu tidak dapat disebut sebagai negara hukum dalam arti yang sesungguhnya. ${ }^{16}$

Berdasarkan prinsip negara hukum yang eksis di dunia, sedikitnya terdapat 12 (dua belas) prinsip pokok sebagai pilar utama yang menyangga berdirinya negara hukum, yakni: ${ }^{17}$

1. Supremasi hukum (supremacy of law).

2. Persamaan dalam hukum (equality before the law).

3. Asas legalitas (due process of law).

4. Pembatasan kekuasaan.

5. Organ-organ penunjang yang independen.

6. Peradilan bebas dan tidak memihak.

7. Peradilan tata usaha negara.

8. Mahkamah Konstitusi (Constitutiuonal Court).

9. Perlindungan hak asasi manusia.

10. Bersifat demokratis.

11. Berfungsi sebagai Sarana Mewujudkan Tujuan Bernegara (Welfare Rechstaat).

12. Transparansi dan Kontrol Sosial.

13 Ridwan H. R., dalam R. Muhamad Ibnu Mazjah, "Kedudukan dan Fungsi Dewan Pers dalam Tatanan Negara Hukum dan Negara Demokrasi”, Prodigy, Vol. 7, No.2, Desember 2019, hal. 284.

14 Jimly Asshiddiqie, Menuju Negara Hukum Yang Demokratis, Jakarta: Buana Ilmu Populer, 2008, hal. 81.

15 Jimly Asshiddiqie, Pengantar Ilmu Hukum Tata Negara, Jakarta: Raja Grafindo Persada, 2013, hal. 281.

16 Jimly Asshiddiqie, Menuju Negara Hukum..., hal. 84.

$17 \quad$ Ibid, hal. 397. 
Pelaksanaan negara hukum yang demokratis (constitutional democracy) dilandasi dengan prinsip-prinsip negara hukum (nomocratie) dan prinsip-prinsip kedaulatan rakyat yang dijalankan secara beriringan, seperti dua sisi mata uang. Manifesto negara hukum demokrasi itu berbuah hukum yang tidak boleh dibuat, ditafsirkan, ditegakkan dengan tangan besi berdasarkan kekuasaan semata (machstaat) ${ }^{18}$

Adapun konsep demokrasi secara umum dikenal sebagai pemerintahan dari rakyat oleh rakyat dan untuk rakyat. Istilah demokrasi berasal dari kata "demos" yang berarti "rakyat" dan "kratos/kratein" yang berarti pemerintahan. Istilah demokrasi berasal dari Yunani Kuno yang diutarakan di Athena Kuno pada abad ke-5 Sebelum Masehi. ${ }^{19}$ Konsep tentang demokrasi tidak lepas dari sejarah tentang pergulatan masyarakat dalam memperjuangkan kesamaan hak dan kedudukannya di hadapan hukum.

Pertentangan terus menerus antara raja yang absolut dengan parlemen telah berlangsung lama dan menghasilkan pengakuan terhadap hak-hak bangsa Inggris, seperti Magna Charta, Petition of Rights, Habeas Corpus Act, dan Bill of Rights. ${ }^{20}$ Pada akhirnya, demokrasi merupakan tatanan hidup bernegara yang menjadi pilihan negara-negara di dunia pada umumnya. ${ }^{21} \mathrm{Hal}$ itu sejalan dengan paham negara hukum yang tidak dapat dipisahkan dari paham kerakyatan, karena hukum yang mengatur dan membatasi kekuasaan negara diartikan sebagai hukum yang dibuat atas dasar kekuasaan atau kedaulatan rakyat. $^{22}$

Memasuki era reformasi, penguatan terhadap paham negara hukum dan demokrasi membawa implikasi terhadap perubahan sistem

Ibid, hal. 398.

19 Nihaya M., "Demokrasi dan Problematikanya di Indonesia", Jurnal Sulesana, Vol. 6, 2011, hal. 15.

20 Andi Hamzah, Perlindungan Hak-Hak Asasi Manusia Dalam Hukum Acara Pidana, Jakarta: Universitas Trisakti, 2010, hal. 2.

21 Benny Bambang Irawan, "Perkembangan Demokrasi di Indonesia", Jurnal Hukum dan Dinamika Masyarakat, Vol. 5, No. 1, Oktober 2007, hal. 54.

22 Juniarso Ridwan dan Achmad Sodik Sudradjat, Hukum Administrasi Negara dan Kebijakan Pelayanan Publik, Bandung: Nuansa, 2012, hal. 11. ketatanegaraan di Indonesia. Senada dengan konsepsi tentang negara hukum tersebut, penguatan itu dimulai dengan dilakukannya amandementerhadap konstitusinegaraRepublik Indonesia, dari UUD Tahun 1945 menjadiUUD NRI Tahun 1945. Amandemen konstitusi pada saat itu dilatarbelakangi adanya arus pemikiran kuat yang dimotori oleh berbagai kampus dan para pegiat demokrasi, yang menyatakan reformasi konstitusi merupakan keharusan jika mau melakukan reformasi. Alasannya ialah krisis multidimensi yang menimpa Indonesia disebabkan oleh sistem politik yang otoriter, sehingga untuk memperbaikinya harus dimulai dari perubahan sistem politik agar menjadi demokratis. Untuk membangun sistem politik yang demokratis, harus dilakukan amandemen terhadap UUD Tahun 1945 karena sistem politik otoriter yang dibangun selalu masuk dari celah-celah yang ada pada UUD Tahun 1945 tersebut. ${ }^{23}$ Amandemen konstitusi secara formal bertujuan untuk menyempurnakan sistem ketatanegaraan, termasuk menata ulang kedudukan, tugas, fungsi, dan wewenang, serta susunan keanggotaan lembaga-lembaga negara. ${ }^{24}$

Perubahan secara signifikan dilakukan terhadap UUD Tahun 1945 khususnya terkait eksistensi lembaga Majelis Permusyawaratan Rakyat (MPR). Sebelum perubahan UUD Tahun 1945, MPR merupakan lembaga tertinggi negara, dengan kekuasaan yang sangat besar. Kekuasaannya tersebut bahkan sangat luar biasa, karena MPR mempunyai kekuasaan tidak terbatas, sebagaimana ditentukan dalam Penjelasan Pasal 3 yang menyatakan "Oleh karena Majelis Permusyawaratan Rakyat Memegang keadulatan negara, maka kekuasaannya tidak terbatas."

Satu hal yang sulit terbantahkan ialah mekanisme checks and balances sebagai unsur

23 Moh. Mahfud M.D., Politik Hukum di Indonesia, Jakarta: Rajawali Pers, 2011, hal. 377.

24 Sutriyanti, "Tinjauan Yuridis Terhadap Kewenangan Majelis Permusyawaratan Rakyat Republik Indonesia (MPR) Dalam Wacana Menetapkan Kembali PokokPokok Haluan Negara”, Prodigy, Vol. 7, No. 2, Desember 2019, hal. 336. 
penting jalannya pemerintahan mengalami stagnasi sebelum periode reformasi, karena pengaruh sistem politik yang tidak demokratis. Kondisi tersebut berlangsung ajeg dalam prosesnya, karena secara konstitusional dikukuhkan dengan ketentuan Pasal 1 ayat (2) UUD Tahun 1945 yang menyatakan "Kedaulatan di tangan rakyat dan dilakukan sepenuhnya oleh Majelis Permusyawaratan Rakyat" dan dikuatkan oleh Penjelasan Pasal 3 UUD NRI Tahun 1945 itu.

Setelah dilakukan amandemen menjadi UUD NRI Tahun 1945, rumusan Pasal 1 ayat (2) mengalami perubahan. Perubahan tersebut berimplikasi pada kedudukan MPR tidak lagi sebagai lembaga tertinggi negara, tetapi sejajar dengan lembaga tinggi negara lainnya, yakni Dewan Perwakilan Rakyat (DPR), Dewan Perwakilan Daerah (DPD), Presiden dan Wakil Presiden, Mahkamah Agung (MA), Mahkamah Konstitusi (MK), Komisi Yudisial (KY), dan Badan Pemeriksa Keuangan (BPK). Hal tersebut mempunyai konsekuensi pada peraturan perundang-undangan di dalam tata hukum tidak lagi mengenal Ketetapan MPR (Tap MPR) sebagai peraturan. ${ }^{25}$. Tap MPR tidak lagi dikeluarkan sebagai peraturan perundangundangan dan tempatnya pada derajat kedua di dalam hierarki peraturan perundang-undangan digantikan oleh undang-undang/Peraturan Pemerintah Pengganti Undang-Undang (Perppu) yang semula menempati derajat ketiga. $^{26}$

Selanjutnya, "frasa kedaulatan rakyat dilaksanakan menurut undang-undang dasar" dalam rumusan Pasal 1 ayat (2) UUD NRI Tahun 1945 mengandung arti representasi dari kedaulatan rakyat bukan hanya terbatas pada MPR. Representasi kedaulatan rakyat juga ada pada lembaga tinggi negara lainnya, yaitu Presiden dan Wakil Presiden, DPD, dan DPR yang dipilih langsung oleh rakyat, serta MK, MA, BPK, dan KY yang dipilih oleh DPR. DPD, MK, dan KY sebagai lembaga

\footnotetext{
25 Moh. Mahfud M.D., Politik Hukum di Indonesia, Jakarta: Rajawali Pers, 2011, hal. 376.

$26 \quad$ Ibid.
}

tinggi negara merupakan lembaga baru, yang pembentukannya ditujukan untuk memperkuat sistem checks and balances sebagai manifestasi asas negara hukum dan asas negara demokrasi.

Gagasan negara hukum yang dicitacitakan dalam UUD NRI Tahun 1945 itu akan dapat direalisasikan, bila seluruh proses penyelenggaraan pemerintahan benarbenar didasarkan pada kaidah-kaidah yang tertuang di dalam konstitusi. ${ }^{27}$ Bagaimanapun pemerintahan yang tidak dikontrol dengan perangkat hukum sangat rentan terhadap berbagai penyimpangan. Oleh karena itu, negara yang ideal acap dilekatkan kepada negara yang semua kegiatan kenegaraannya didasarkan pada hukum, khususnya sejak abad ke XX. ${ }^{28}$ Sehubungan dengan hal tersebut, MK dibentuk atas pertimbangan pentingnya usaha menegakan konstitusi dan prinsip negara hukum sebagaimana diamanatkan dalam UUD NRI Tahun 1945. ${ }^{29}$ MK sebagai salah satu pelaku kekuasaan kehakiman berfungsi melakukan kontrol untuk menguji undangundang terhadap undang-undang dasar pada tingkat pertama dan terakhir yang putusannya bersifat final. ${ }^{30}$

Keberadaan lembaga-lembaga negara baru dalam sistem ketatanegaraan Republik Indonesia pasca-amandemen UUD NRI Tahun 1945 menjalankan fungsinya pada posisi yang berbeda-beda, baik di cabang kekuasaan yudikatif, legislatif, maupun eksekutif berupa lembaga negara mandiri, yang di dalam UUD NRI Tahun 1945 tidak tersebut secara tekstual. Begitu pula, alas yuridis pembentukan lembagalembaga negara baru tersebut berupa peraturan perundang-undangan dari tingkat undangundang hingga pada tingkat peraturan presiden. Hal ini dapat dimengerti karena ketentuan di dalam konstitusi juga tidak memuat semua

\footnotetext{
27 Irianto A Baso Ence, dalam Janpatar Simamora, Analisa Yuridis Terhadap Model Kewenangan Judicial Review di Indonesia, hasil penelitian Lembaga Penelitian Universitas HKBP Nommensen, Medan, 2012, hal. 389.

28 Padmo Wahyono dalam Janpatar Simamora, Ibid.

29 Konsiderans Menimbang huruf b Undang-Undang Nomor 24 Tahun 2003 tentang Mahkamah Konstitusi.

30 Pasal 24C Undang-Undang Dasar Negara Republik Indonesia Tahun 1945.
} 
lembaga negara yang menjadi padanan daripada keberadaan lembaga negara mandiri itu yang disebutkan secara tegas. Salah satu sebabnya karena pengaturan konstitusi hanya mengatur hal-hal yang bersifat dasar untuk penyelenggaran negara. Namun demikian, lembaga negara mandiri memiliki tujuan luhur untuk merefleksikan asas negara hukum menuju cita hukum ideal yang diharapkan. Pembentukan lembaga itu tetap bertujuan untuk memberikan penguatan terhadap sendi-sendi kedaulatan rakyat, melalui sistem check and balances sebagai bentuk pengawasan terhadap penyelenggaraan kekuasaan.

\section{B. Ide Pengawasan dalam Pembentukan Komisi Kejaksaan RI}

Ide tentang pembentukan lembaga pengawasan inklusif dengan lahirnya lembaga tinggi negara baru tersebut sulit dilepaskan dari semangat reformasi yang berperan sebagai titik anjak dari penataan sistem ketatanegaraan. Berbagai upaya dilakukan pemerintah untuk menyerap aspirasi masyarakat yang menghendaki perubahan menuju pemerintahan yang transparan, bersih, dan bebas dari korupsi, kolusi, dan nepotisme (KKN). Memasuki awal reformasi, aspirasi tersebut satu diantaranya adalah membentuk sebuah lembaga pengawasan terhadap Penyelenggara Negara, bernama Komisi Ombudsman Nasional.

Langkah pembentukan KomisiOmbudsman Nasional melalui Keputusan Presiden (Keppres) Nomor 44 Tahun 2000 merupakan langkah cepat dalam mengatasi desakan masyarakat terhadap pelayanan umum dan pemberantasan KKN yang sudah sedemikian kuat. Disebut langkahcepatkarenadalam proses pembentukan Komisi Ombudsman Nasional terjadi dalam waktu yang relatif singkat di tengah perbedaan pandangan terkait apakah Komisi Ombudsman Nasional cukup dibentuk melalui Keppres atau berdasarkan undang-undang. ${ }^{31}$

Proses pembentukan Komisi Ombudsman Antonius melalui proses yang cepat yang tak luput diwarnai dengan perbedaan pandangan dapat dilihat pada: Antonius Sujata et all, Ombudsman Indonesia Masa Lalu, Sekarang dan Mendatang, Jakarta: Komisi Ombudsman Nasional, 2002, hal. 2.
Pada akhirnya, agar tidak menghabiskan waktu terlalu lama, Antonius Sujata ${ }^{32}$ berpendapat pembentukan lembaga ombudsman sebaiknya diwujudkan secara konkrit melalui Keppres, dengan catatan Keppres tersebut memberikan mandat kepada Anggota Ombudsman untuk menyusun draft RUU Ombudsman Nasional. ${ }^{33}$ Lahirnya Komisi Ombudsman Nasional merupakan babak baru dalam tatanan sistem pengawasan di Indonesia, karena merupakan satu-satunya lembaga pengawas yang memiliki jaringan dan dukungan luas dari masyarakat internasional. Di sisi lain, Komisi Ombudsman Nasional yang telah mengalami penguatan secara kelembagaan menjadi Ombudsman Republik Indonesia berdasarkan UU No. 37 Tahun 2008 tentang Ombudsman Republik Indonesia. Ombudsman Republik Indonesia adalah institusi yang memiliki kesamaan rumpun dengan KKRI sebagai lembaga mandiri yang bertugas melakukan pengawasan.

Upaya pemerintah untuk memperkuat sendi pemerintahan yang bersih dan bebas KKN terus berlanjut. Memasuki tahun 2004, Presiden Susilo Bambang Yudhoyono menyadari bahwa permasalahan korupsi di Indonesia sudah meradang dan tersistematis, sehingga dikeluarkanlah instruksi presiden kepada seluruh jajaran pemerintahan agar segera memikirkan langkah-langkah percepatan strategi pencegahan dan pemberantasan korupsi melalui Instruksi Presiden (Inpres) Nomor 5 Tahun 2004. ${ }^{34}$ Setelah melalui proses yang panjang, komitmen pemerintah tersebut dituangkan ke dalam dokumen Strategi Nasional Pencegahan dan Pemberantasan Korupsi Jangka Panjang (2012-2025) dan jangka menengah (2012-2014). Pada dokumen tersebut sejumlah permasalahan telah berhasil diidentifikasi yang beberapa di antaranya: ${ }^{35}$

\footnotetext{
32 Antonius Sujata adalah Ketua Komisi Ombudsman pertama yang pada waktu itu turut membidani proses lahirnya lembaga tersebut.

33 Antonius Sujata et all, Ombudsman Indonesia Masa ..., hal. 33.

34 Ajeng Triwahyuni, "Strategi Penguatan Komisi Kejaksaan dalam Mendorong Pencegahan dan Pemberantasan Korupsi”, Teropong, Volume 1, 2013, hal. 33.

35 Ibid, hal. 34.
} 
1. belum tuntasnya reformasi birokrasi yang menyeluruh yang (beberapa) di antaranya ditunjukkan oleh minimnya integritas, belum tersusunnya manajemen kinerja dan standar pelayanan minimal;

2. masih minimnya badan publik yang menerapkan keterbukaan informasi menyangkut administrasi dan pelayanan publik, termasuk penanganan perkara, Kendati UU No.14 Tahun 2008 tentang Keterbukaan Informasi Publik dan UU No.25 Tahun 2009 tentang Pelayanan Publik telah diberlakukan;

3. rendahnya penanganan pengaduan masyarakat dan pelaporan (whistleblowing) yang ditindaklanjuti akibat belum optimalnya mekanisme dan infrastruktur pengaduan publik;

4. absennya kepercayaan (trust) di tengah masyarakat yang melahirkan ketidakpuasan terhadap lembaga hukum beserta aparaturnya;

5. pengawasan terhadap lembaga, aparatur, maupun unsur-unsur profesi terkait penegakan hukum, masih lemah; dan

6. partisipasi masyarakat, baik selaku pelapor maupun saksi, masih belum didukung oleh keterjaminan mereka atas perlindungan hukum yang sepatutnya diterima. Ditambah lagi, mekanisme pengaduan masyarakat juga belum memadai.

Identifikasi masalah tersebut pada intinya merupakan cermin lemahnya penyelenggaraan negara, yang didasarkan kepada prinsip good governance sebagai perwujudan dari asas negara hukum dan asas negara demokrasi. Penguatan sektor pengawasan melalui pembentukan lembaga pengawas eksternal pada lembaga penegak hukum sebagai cerminan dari asas negara hukum dan demokrasi. Oleh karenanya, dipandang sebagai salah satu sarana yang tepat untuk menciptakan sistem yang efektif, bersih, dan akuntabel dalam upaya memperkecil peluang terjadinya tindak pidana korupsi. Penguatan sektor pengawasan juga mencerminkan perwujudan sektor negara hukum, melalui sarana hukum administrasi.
Menurut Ajeng Tri Wahyuni, terdapat dua alasan yang menjadi dasar pembentukan lembaga pengawas eksternal untuk mengawasi sebuah lembaga penegak hukum. Pertama, pengawasan internal yang dilakukan oleh lembaga penegak hukum itu tidak berjalan secara efektif dan kental dengan praktik KKN dan kedua, lembaga penegak hukum tersebut memerlukan kepercayaan dan dukungan publik untuk melaksanakan tugas dan fungsinya ${ }^{36}$. Sejalan dengan itu, Nur Syarifah mengutarakan lembaga-lembaga pengawas konvensional dianggap lemah dan gagal melaksanakan fungsi tertentu, hingga menuntut dibentuknya lembaga-lembaga baru di luar konvensional untuk mengatasi kelemahan atau kegagalan tersebut ${ }^{37}$. Pengawas internal ini dinilai memiliki beragam permasalahan yang membuat fungsi pengawasan belum dapat berjalan sebagaimana mestinya, karena adanya kelemahan pada aspek kemandirian dan semangat membela korps yang relatif tinggi, rendahnya kualitas dan integritas personel pengawas, dan sistem pengawasan internal yang lemah. ${ }^{38}$

Tak terkecuali di lembaga kejaksaan, penguatan sektor pengawasan terhadap lembaga ini juga merupakan mata rantai yang amat penting dalam konteks penegakan hukum dalam bingkai sistem peradilan pidana terpadu (integrated criminal justice system). Kejaksaan sebagai salah satu elemen sistem hukum menempati posisi sentral dan mempunyai peranan strategis di dalam suatu negara hukum. Posisi sentral dan peranan strategis ini dikarenakan kejaksaan berada di poros dan filter antara proses penyidikan dengan proses pemeriksaan di persidangan, selain sebagai pelaksana penetapan dan keputusan pengadilan. Oleh karena itu, kejaksaan diharapkan untuk selalu meningkatkan kinerjanya secara profesional, berintegritas, transparan, dan akuntabel..$^{39}$

Ajeng Triwahyuni, Strategi Penguatan Komisi ..., hal. 34.

7 Nursyariffah, "Menuju Efektifitas Kewenangan Komisi Kejaksaan”, Teropong, Vol. 1, November 2013, hal. 15.

38 Coky R. Ramadhan, "Kedudukan, Tugas, dan Kewenangan Komisi Kejaksaan”, Teropong, Vol. 1, November 2013, hal. 5.

39 Marwan Effendy, dalam Sri Hastuti dan Lasmaida Limbong, "Pengukuran Kepuasan Masyarakat Terhadap Kinerja Kejaksaan Dalam Penanganan Perkara”, Jurnal Bina Adhyaksa, Vol. 6, Edisi 3, Juli 2016, hal. 227. 
Cita hukum tersebut sejatinya tertuang di dalam Pasal 38 UU No. 16 Tahun 2004 tentang Kejaksaan RI (UU No. 16 Tahun 2004) berbunyi "Untuk meningkatkan kualitas kinerja kejaksaan, presiden dapat membentuk sebuah komisi yang susunan dan kewenangannya diatur oleh presiden." Komisi yang dimaksud adalah Komisi Kejaksaan Republik Indonesia. Kata "dapat" dalam Pasal 38 UU No. 16 Tahun 2004 bermakna pembentukan KKRI bersifat fakultatif. Namun, lahirnya komisi pengawas ini menjadi sebuah kebutuhan yang tidak lagi bisa ditawar dan tuntutan yang sangat mendesak. Hal ini dikarenakan adanya reformasi hukum dan adanya pelaksanaan fungsi pengawasan terhadap kejaksaan yang memiliki kewenangan besar di bidang penuntutan serta kewenangan lainnya. Oleh karena itu, gagasan untuk membentuk Komisi Kejaksaan merupakan jawaban terhadap ketidakefektifan sistem pengawasan internal (fungsional) yang telah terbangun (built in) dalam tubuh kejaksaan yang diperankan Jaksa Agung Muda Pengawasan. ${ }^{40}$

Ketidakefektifan pengawasan internal ini terjadi karena berbagai faktor yang meliputi kualitas dan integritas pengawas yang tidak memadai, pengawasan yang tidak transparan sehingga tidak terjangkau oleh kontrol publik, belum adanya kemudahan bagi masyarakat yang dirugikan menyampaikan pengaduan dan memantau proses serta hasilnya (ketiadaan akses), masih menonjolnya semangat membela sesama korps (esprit de corps), dan tidak terdapat kehendak yang kuat dari pimpinan puncak lembaga penegak hukum untuk menindaklanjuti hasil-hasil pengawasan. ${ }^{41}$ Selain itu, efektifitas pengawas eksternal juga dibutuhkan karena perangkat pengawas internal dimanapun dan pada level apapun merupakan bagian dari badan/instansi yang diawasi. ${ }^{42}$

40 Mas Achmad Santosa, "Komisi Kejaksaan", Artikel Majalah Tempo (21 Februari 2005), https://majalah.tempo. $\mathrm{co} / \mathrm{read} / \mathrm{kolom} / 105299 /$ komisi-kejaksaan?hidden $=\operatorname{login}$, diakses tanggal 9 Maret 2020.

$41 \quad$ Ibid.

42 Masdar F. Mas'udi, "Ombudsman Melawan Positivisme Hukum demi Good Governance dan Keadilan", Artikel dalam Peranan Ombudsman Dalam Pemberantasan Dan Pencegahan Korupsi Serta Pelaksanaan Pemerintahan yang Baik, Jakarta: Komisi Ombudsman Nasional, 2005, hal. 37.
Lembaga KKRI akhirnya lahir pada tahun 2005 dengan terbitnya Perpres No. 18 Tahun 2005 tentang Komisi Kejaksaan Republik Indonesia (Perpres No. 18 Tahun 2005) yang kemudian mengalami revisi dengan Perpres No.18Tahun 2011. Berkaitan dengan kedudukan KKRI yang lahir dengan alas yuridis setingkat perpres, penulis berpendapat hal itu tidak terlepas dari keberadaan lembaga Kejaksaan Republik Indonesia tidak disebutkan secara tegas di dalam konstitusi. Eksistensi Kejaksaan Republik Indonesia di dalam konstitusi hanya tersirat di dalam Pasal 24 UUD NRI Tahun 1945 yang berbunyi "Kekuasaan kehakiman dilakukan oleh sebuah Mahkamah Agung dan lain-lain badan menurut undang-undang." Selanjutnya, kedudukan lembaga Kejaksaan Republik Indonesia berdasarkan undang-undang organik berada dalam ranah eksekutif. Hal ini sebagaimana diatur dalam Pasal 2 ayat (1) UU No. 16 Tahun 2004 tentang Kejaksaan Republik Indonesia, yang menyatakan "Kejaksaan Republik Indonesia yang selanjutnya dalam Undang-Undang ini disebut kejaksaan adalah lembaga pemerintah yang melaksanakan kekuasaan negara di bidang penuntutan serta kewenangan lain berdasarkan undang-undang." Berdasarkan hal tersebut, secara praktis lebih mudah untuk mengimplementasikan politik hukum pemerintah terkait pengawasan terhadap lembaga kejaksaan melalui Peraturan Presiden.

\section{Implementasi Hukum Progresif dalam Tugas Pengawasan pada Perpres No. 18 Tahun 2011 tentang Komisi Kejaksaan Republik Indonesia}

\section{A. Makna Hukum Progresif dalam} Penegakan Hukum di Indonesia

Salah satu penataan dan reorientasi bidang penegakan hukum pasca-reformasi melalui amandemen konstitusi dilakukan dengan memasukan frasa "untuk menyelenggarakan peradilan guna menegakan hukum dan keadilan" sebagaimana dirumuskan dalam Pasal 24 ayat (1) UUD NRI Tahun 1945. Terminologi hukum dan keadilan dimaknai sebagai dua aspek yang berbeda, tetapi keduanya 
merupakan satu kesatuan yang tak dapat dipisahkan. Gustav Radbruch membuat suatu analogi yang berhubungan dengan hukum dan keadilan. Hukum yang dianalogikan sebagai sein dan keadilan sebagai sollen, ibarat dua sisi dari sisi mata uang; materi mengisi "bentuk" dan bentuk mengisi "materi" ${ }^{43}$. Nilai keadilan di mata Radbruch adalah materi yang menjadi isi aturan hukum dan aturan hukum adalah bentuk yang melindungi nilai keadilan. ${ }^{44}$ Dalam pada itu dikenal tiga tujuan hukum yakni keadilan, kemanfaatan, dan kepastian hukum. Sekalipun ketiganya merupakan nilai dasar dari hukum, namun di antara ketiganya itu terdapat ketegangan satu sama lain. Terjadinya hubungan atau keadaan yang demikian itu dikarenakan ketiganya berisi tuntutan yang berlainan dan satu sama lain mengandung potensi untuk saling bertentangan. ${ }^{45}$

Hal yang sulit dibantah, yaitu pertentangan itu bertolak dari persoalan sistem hukum di Indonesia lebih condong bercorak sistem hukum civil law (civil law system) dengan karakteristik hukum yang bersifat tertulis. Karakter hukum tertulis dikenal terletak pada kekakuannya karena bertumpu pada doktrin lex dura sed tamen scripta (hukum itu keras/kaku). Kekakuan hukum tertulis berakibat pada proses penegakan hukum yang acap terjebak kepada pola berhukum berdasarkan peraturan yang tertulis saja. Pada titik itu, aspek kepastian hukum lebih menonjol. Hal itu tetap dapat dibenarkan, karena karakteristik hukum sebagai ilmu terapan mempunyai pola nalar utama dalam berhukum dengan memahami hukum sebagai sebuah dogma.

Namun demikian, kekeliruan dalam memahami hukum semata-mata sebagai teks tertulis terkadang mengabaikan aspek terpenting lain, misalnya, filosofi yang terkandung dalam suatu teks perundang-undangan, aspek

43 Bernard L Tanya, et. al., Teori Hukum Strategi Tertib Manusia Lintas Ruang dan Generasi, Yogyakarta: Genta Publising, 2010, hal. 129.

$44 \quad$ Ibid.

45 Satjipto Rahardjo dalam Ronny Rahman Nitibaskara, Tegakkan Hukum Gunakan Hukum, Jakarta: Kompas, 2007, hal. 60. sosiologis yang diterjemahkan secara sederhana sebagai sebuah nilai keadilan berdasarkan akal sehat (common sense) dan hati nurani. Praktik dalam berhukum secara kaku sebagaimana dimaksud seringkali terjadi bahkan populer dalam beberapa tahun belakangan ini, seperti dalam putusan Peninjauan Kembali Mahkamah Agung No. 83 K/PID.SUS/2019 juncto Putusan Kasasi No. 574 K/PID.SUS atas nama terdakwa Baiq Nuril. Putusan tersebut dipandang masyarakat umum mencederai rasa keadilan karena akal sehat memandang Baiq Nuril yang duduk sebagai terdakwa dalam kasus tersebut sejatinya adalah korban pelecehan seksual.

Perkara hukum yang juga menyita perhatian publik karena nilai kemanusiaan adalah kasus Samirin, 69 tahun, yang dipidana penjara 2 bulan 4 hari karena mencuri 1,9 Kilogram getah rambung seharga $\mathrm{Rp} 17.480$ milik PT Bridgestone di Kecamatan Dolok Kabupaten Simalungun, Provinsi Sumatera Utara, karena melanggar ketentuan pidana Pasal 107 huruf UU No. 39 Tahun 2014 tentang Perkebunan. ${ }^{46}$ Ironisnya jaksa penuntut umum menuntut terdakwa dengan tuntutan pidana 10 bulan penjara. Perkara hukum ini syarat dengan nuansa hukum yang dinilai hanya mengandalkan kekuatan tekstual pasal-pasal di dalam undang-undang.

Beberapa perkara tersebut berada di luar asas kepastian, sehingga menimbulkan keresahan di tengah masyarakat karena hukum seharusnya bisa menerobos ruang ketidakadilan. Pada titik ini, hukum progresif menempatkan diri. Hukum progresif tidak menerima hukum yang mutlak serta final, tetapi sangat ditentukan oleh kemampuannya mengabdi kepada manusia karena hukum adalah suatu institusi yang bertujuan mengantarkan manusia kepada kehidupan yang sejahtera dan membuat manusia bahagia. ${ }^{47}$ Hukum progresif

\footnotetext{
46 CNN Indonesia. 6 Januari 2020. "Ambil Getah Karet Senilai Rp17 Ribu, Samirin Dibui 2 Bulan”, https://www. cnnindonesia.com/nasional/20200116141042-12-465939/ ambil-getah-karet-senilairp17ribu-samirin-dibui-2-bulan, diakses tanggal 1 April 2020.

47 Satjipto Rahardjo, Hukum Progresif Sebuah Sintesa Hukum Indonesia, Yogyakarta: Genta Publishing, 2009, hal. 2.
} 
menitikberatkan fungsi hukum untuk manusia, bukan manusia untuk hukum.

Hukum progresif berhimpitan dengan teori hukum alam yang mengajarkan tentang pencarian keadilan dengan bersumber kepada tatanan moral yang oleh Hans Kelsen disebut dengan Meta Juridika. Sandaran moral itu pula yang mendorong pemikiran hukum progresif lebih mendahulukan kepentingan manusia daripada menafsirkan hukum dari sudut logika dan peraturan. ${ }^{48}$ Banyak yang tidak terwadahi dalam teks tertulis, seperti suasana dan kebutuhan-kebutuhan yang ada pada suatu saat, serta moral yang dipeluk masyarakat pada suatu kurun waktu tertentu, tidak mungkin terekam dalam teks hukum tersebut. ${ }^{49}$ Pada titik inilah, hukum progresif mengatributkan hukum kepada perilaku (behavior) manusia, dengan segala tindakan bersikap progresif, solutif, dan manusiawi.

Jejak pemikiran hukum progresif sejatinya telah mewarnai dunia hukum di Indonesia yang secara monumental tertuang di dalam Pasal 24 ayat (1) UUD NRI Tahun 1945. Hal itu juga memberikan arti positif karena menjadi landasan berpikir bagipenegakan hukum agar menggunakan hati nurani. Landasan hati nurani menjadi sebuah norma dalam hal pembentukan undang-undang. Bahkan, salah satunya adalah UU No. 16 Tahun 2004, yang mengatur syarat penuntutan harus didasarkan pada hati nurani selain pada aspek hukum belaka. Kasus Samirin yang mencuri getah rabung dan kasus Baiq Nuril, dalam kaca mata hukum progresif, menggambarkan betapa hukum tidak digali. Konsep keadilan restoratif (restorative justice) yang diabaikan dan hukum yang melulu bersifat represif pada akhirnya mencederai rasa keadilan itu sendiri.

B. Implementasi Hukum Progresif dalam Tindak Lanjut Laporan Pengaduan Masyarakat dalam Perpres Nomor 18 Tahun 2011

Penyelenggaraan hukum progresif sebenarnya tidak hanya menekankan pada

$48 \quad$ Ibid.

49 Satjipto Rahardjo, Penegakan Hukum Progresif, Jakarta: Kompas, 2010, hal. 11. aspek perilaku nyata para pelaku hukum dengan mengabaikan peran dari sistem hukum dimana mereka berada. Lebih dari itu, hukum progresif memiliki dua aspek, yaitu sistem dan manusia. ${ }^{50}$ Para pelaku hukum dapat bertindak progresif, apabila sistem yang berlaku menghambat, bahkan hingga pada tindakan yang menabrak aturan hukum sekalipun.

Tindakan yang bertentangan yang dilakukan hingga menabrak aturan hukum itu memang dapat menimbulkan pro dan kontra di dalam dunia akademis. Namun terlepas dari itu, penulis berpendapat tindakan pelaku hukum yang dilakukan hingga menabrak aturan hukum dapat ditempuh sepanjang tetap didasarkan pada nilai dan norma yang hidup di masyarakat. ${ }^{51}$ Penulis juga berpendapat langkah tersebut harus disusul dengan upaya nyata dari para pemangku kebijakan, untuk melakukan perbaikan sisi regulasi dengan pembentukan maupun revisi peraturan perundang-undangan yang ada, sebagai suatu bagian yang tak terpisahkan dari upaya perbaikan hukum dari aspek sistem.

Sebagaimana telah diuraikan, pertentangan aspek sistem dan keadilan yang bertumpu kepada akal sehat itu terjadi karena sistem yang terbungkus dalam teks tertulis tidak digali, agar rasa keadilan dapat dirasakan. Penafsiran sebaliknya (a contrario) dengan teks tertulis dan ketiadaan teks tertulis yang mengkooptasi pelaku hukum di dalam suatu peraturan perundang-undangan, penggunaan hukum progresif justeru dijadikan perspektif sebagai batu uji dalam analisis penulisan ini.

Minimnya pengaturan tertulis dalam suatu perundang-undangan hendaknya mendorong sikap penegak hukum untuk berinovasi mencari keadilan dalam ruang penegakan hukum yang dirasa sempit. Hal demikian dalam konteks penyelenggaraan negara merupakan bagian dari mata rantai yang turut mendukung suksesnya pembangunan nasional secara menyeluruh yang didasarkan pada nilai keadilan, melalui sarana

\footnotetext{
Satjipto Rahardjo, Hukum Progresif Sebuah ..., hal. 13.

Perbedaan antara aturan hukum dengan norma hukum dapat dilihat pada Peter Mahmud Marzuki, Penelitian Hukum, Jakarta: Prenadamedia, 2011, hal. 45-54.
} 
pemikiran progresif. KKRI sebagai penyangga fungsi penegakan hukum yang dilakukan oleh Kejaksaan RI seharusnya memainkan peranan sesuai tugas dan fungsinya. Berdasarkan Pasal 4 huruf a Perpres No. 18 Tahun 2011, KKRI dalam menjalankan tugas pengawasan berwenang menerima dan menindaklanjuti lapdumas.

Di dalam praktik, pelaksanaan tugas dan kewenangan KKRI berkenaan dengan frasa "menindaklanjuti" lapdumas menimbulkan kegamangan. Hal itu terjadi karena kewenangan atribusi yang diberikan kepada KKRI berdasarkan Pasal 4 huruf a mengandung norma terbuka (open texture). Selain itu, disebabkan juga hukum acara untuk menindaklanjuti lapdumas secara tekstual tidak tertulis dalam Perpres No. 18 Tahun 2011. Oleh karena itu, di dalam penerapannya diperlukan adanya penemuan hukum berkaitan dengan pertanyaan yang meliputi, seperti apa bentuk tindak lanjut yang dapat dilakukan oleh KKRI dan apakah KKRI berwenang untuk melakukan, pemeriksaan, penertiban, penindakan dan pembinaan, di luar pengaturan pemeriksaan ulang, pemeriksaan tambahan dan pengambilalihan pemeriksaan.

Kesan gamang itu dikhawatirkan menghambat kinerja KKRI untuk menjadi garda terdepan di bidang pengawasan untuk memperbaiki kualitas kinerja kejaksaan. Hambatan terhadap penyelesaian lapdumas, antara lain, adanya kekhawatiran tidak terpenuhinya harapan masyarakat terhadap kehormatan aparat agar terjaga dari siap tercela serta marwah institusi dalam mengemban amanah penegakan hukum, sehingga prosesnya dapat berjalan secara benar, mengacu kepada proses hukum yang patut. Berdasarkan alasanalasanitu, diperlukan pemikiran hukum progresif untuk menjalankan tugas dan kewenangan dalam menindaklanjuti lapdumas tersebut. Bertumpu kepada perspektif hukum progresif, penggalian hukum dari aspek sistem dimulai melalui penafsiran atau interpresi untuk menjadi dasar dalam menjawab persoalan tersebut. Hal ini disebabkan penafsiran merupakan jembatan penting dalam penerapan ketentuan hukum yang tepat, sehingga terbentuk penegakan hukum yang baik. ${ }^{52}$

Menurut Peter Mahmud Marzuki, interpretasi dibedakan berdasarkan kata-kata undang-undang, interpretasi berdasarkan kehendak pembentuk dalam undang-undang, interpretasi sistematis, interpretasi historis, interpretasi teleologis, interpretasi antisipatoris, dan interpretasi modern. ${ }^{53}$ Tulisan ini menggunakan interpretasi berdasarkan katakata, interpretasi sistematis, dan teleologis, atau sosiologis. Bentuk interpretasi yang paling awal adalah "interpretasi berdasarkan katakata" yang terdapat di dalam suatu peraturan perundang-undangan. Interpretasi berdasarkan kata-kata, beranjak dari kata-kata yang tertuang di dalam undang-undang. Secara harfiah, menindaklanjuti diartikan "mengambil tindakan untuk langkah-langkah selanjutnya". ${ }^{54}$ Untuk melakukan langkah-langkah selanjutnya, tetap diperlukan batasan yang jelas. Namun, Perpres No. 18 Tahun 2011 tidak mengatur secara jelas dan rinci tindakan apa yang harus diambil untuk langkah-langkah selanjutnya.

Berdasarkan aspek "sistem", menggali hukum untuk menjawab tuntutan keadilan dilanjutkan dengan melakukan interpretasi sistematis dan interpretasi teleologis. Menurut Sudikno Mertokusumo, interpretasi sistematis, yaitu penafsiran ketentuan peraturan perundang-undangan dengan menghubungkan peraturan hukum atau undang-undang lain atau dengan keseluruhan sistem hukum..$^{55}$ Interpretasi sistematis berpijak pada pemikiran tentang peraturan yang banyak dan beraneka warna itu tidak merupakan hutan belukar yang sukar dan bahaya untuk diambil kemanfaatannya, tetapi supaya menjadi teratur

52 Hwian Christianto, "Penafsiran Hukum Progresif Dalam Perkara Pidana”, Mimbar Hukum, Vol. 23, No. 3, Oktober 2011, hal. 479.

53 Peter Mahmud Marzuki, Penelitian Hukum, Jakarta: Prenadamedia, 2011, hal. 150.

54 Arti kata tindak lanjut diakses dari https://kbbi.web.id/ tindak\%20lanjut.

55 Eddy O.S. Hiariej, dalam Prianter Jaya Hairi "Judicial Review Pasal-Pasal Makar KUHP: Perspektif Penafsiran Hukum dan HAM", Negara Hukum, Vol. 8, No. 2, November 2017, hal. 244. 
dan berguna bagi masyarakat. ${ }^{56}$ Adapun interpretasi teleologis atau sosiologis, yaitu cara penafsiran untuk mengetahui makna atau yang didasarkan pada tujuan kemasyarakatan terhadap lahirnya suatu undang-undang.

Bertolak dari frasa "menindaklanjuti", maka regulasi yang dapat dirujuk adalah peraturan perundang-undangan yang memuat ketentuan hukum acara yang berhubungan dengan bidang pengawasan personel kejaksaan. Regulasi tersebut mengarah pada PP No. 20 Tahun 2008 tentang Tata Cara Pemberhentian Dengan Hormat, Pemberhentian dengan Tidak Hormat, dan Pemberhentian Sementara, serta Hak Jabatan Fungsional Jaksa yang Terkena Pemberhentian (PP Nomor 20 Tahun 2008). Ketentuan di PP No. 20 Tahun 2008 mengatur keterlibatan lembaga pengawas internal yang dipimpin oleh Jaksa Agung Muda Pengawasan (Jamwas). Hal yang perlu digarisbawahi dari pengaturan itu, yakni pada pelaksanaan tugas pengawasan oleh pengawas internal melekat pengawasan fungsional yang berfungsi sebagai perangkat teknisnya.

PP No. 20 Tahun 2008 dirujuk tidak sekadar dilandasi pada preferensi hukum yang acap digunakan sebagai asas apabila terjadi konflik norma, tetapi didasarkan pada proses penalaran dengan menyandarkan kepada analogi ketentuan jika pada kedua ketentuan perundang-undangan a quo memiliki irisan terkait isu perangkat pengawasan fungsional. Di sinilah proses penggalian hukum secara progresif dari aspek sistem tanpa mengabaikan ketentuan hukum yang ada. Upaya melakukan penemuan hukum dengan bertumpu pada hukum progresif termasuk di dalamnya adalah dengan cara menggali hukum melalui penafsiran hukum secara tepat, dalam bingkai tujuan mencapai cita hukum yang berkeadilan.

Penjelasan Pasal 3 ayat (3) PP No. 20 Tahun 2008 berisi tentang makna pengawasan fungsional adalah kegiatan pengawasan berupa pengamatan, penelitian, pengujian, penilaian, pemberian bimbingan, dan penertiban serta

56 Moeljatno, Asas-Asas Hukum Pidana, Jakarta: Rineka Cipta, 2017, hal. 13. pengusutan, pemeriksaan, penindakan, dan pemantauan terhadap pelaksanaan tugas semua unsur kejaksaan serta sikap, perilaku, dan tutur kata pegawai kejaksaan sesuai dengan peraturan perundang-undangan, rencana strategik, serta kebijakan yang ditetapkan oleh Jaksa Agung Republik Indonesia. Pada fase ini, pengawasan fungsional dilaksanakan oleh pejabat pengawasan fungsional. Namun, terminologi pengawasan fungsional ini di dalam Perpres No. 18 Tahun 2011 tidak diketemukan ketentuannya secara tertulis.

Padahal, kegiatan atau tindakan yang tercakup dalam pengawasan fungsional jelas dibutuhkan sebagai sarana untuk menindaklanjuti lapdumas sehingga kebenaran tentang ada tidaknya dugaan pelanggaran yang dilakukan dapat diuji. Dengan kata lain, pengujian itu membutuhkan serangkaian kegiatan yang meliputi pemantauan, pengumpulan data, pemeriksaan, pengusutan, dan penelaahan. Berdasarkan rangkaian kegiatan tersebut, ditariklah sebuah kesimpulan untuk menghasilkan penilaian yang kemudian dituangkan ke dalam rekomendasi, baik kepada Jaksa Agung dan kepada Presiden. Ketiadaan pengaturan teknis yang bersifat fungsional ini merupakan titik pangkal yang menyebabkan munculnya asumsi KKRI tidak berwenang melakukan proses pemeriksaan.

Pemeriksaan yang tersurat di dalam Perpres No. 18 Tahun 2011, hanya terkait pemeriksaan ulang, pemeriksaan tambahan, dan pengambilalihan pemeriksaan. Ketiga model pemeriksaan tersebut merupakan kewenangan KKRI dalam melakukan pemeriksaan, setelah pengawas internal kejaksaan melakukan tindak lanjut terlebih dahulu atas suatu lapdumas. Sementara di dalam praktik yang berjalan, pemaknaan dalam menindaklanjuti lapdumas tidak bersifat detail, seperti halnya pengawasan fungsional yang telah disebutkan.

Penjabaran tugas dan kewenangan KKRI untuk menindaklanjuti lapdumas di dalam prosesnya turut melibatkan Kejaksaan Agung, dengan melahirkan suatu Nota Kesepahaman. Nota Kesepahaman telah 
disepakati oleh Jaksa Agung RI dengan Ketua KKRI pada 19 Mei 2011, dengan Nomor Kep-009/A/JA/05/2011 dan Nomor NK-001/ KK/05/2011 tentang Mekanisme Kerja Antara Kejaksaan RI dengan Komisi Kejaksaan RI dalam Melaksanakan Pengawasan, Pemantauan dan Penilaian atas Kinerja dan Perilaku Jaksa dan Pegawai Kejaksaan. Berdasarkan Pasal 3, Nota Kesepahaman tersebut bertujuan untuk tercapainya kesepahaman dalam menafsirkan dan melaksanakan ketentuan Pasal 3 sampai dengan Pasal 14 Peraturan Presiden RI Nomor 18 Tahun 2011 tentang Komisi Kejaksaan.

Adapun berkenaan dengan frasa "menindaklanjuti" lapdumas, Nota Kesepahaman tersebut memuat penafsiran secara implisit tentang makna tindak lanjut hanya sebatas penelitian berkas. Pasal 2 huruf a tersebut berbunyi "Lapdu/Lapmas yang disampaikan ke Komisi Kejaksaan perihal kinerja serta perilaku para jaksa dan atau/pegawai akan diteliti/ditelaah oleh para komisioner dan kemudian akan dibahas dalam rapat pleno untuk diambil keputusan sebagai tindak lanjut penyelesaian lapdu/lapmas tersebut". Seiring dengan itu, Pasal 2 huruf b berbunyi "Komisi Kejaksaan akan merekomendasikan kepada Jaksa Agung RI untuk menindaklanjuti lapdu/ lapmas sebagai hasil putusan rapat pleno".

Berdasarkan Pasal 2 huruf a dan Pasal 2 huruf b Nota Kesepahaman Jaksa Agung RI dengan Ketua KKRI tertanggal 19 Mei 2011, dapatlah diketahui bahwa Komisi Kejaksaan menafsirkan tugas dan kewenangan menindaklanjuti lapdumas terbatas pada penelitian/penelahaan, baik dari sisi administrasi maupun substansi, hingga pada pembahasan rapat pleno Komisi Kejaksaan. Adapun tindak lanjut dalam arti pelaksanaan pengawasan fungsional untuk mengungkap ada atau tidaknya dugaan pelanggaran terkait kode etik, yaitu Komisi Kejaksaan akan menyerahkkan kepada Jaksa Agung untuk ditindaklanjuti oleh pengawas internal kejaksaan.

Nota Kesepahaman ini mendasari sikap hukum KKRI terkait kewenangan menindaklanjuti lapdumas melalui serangkaian tindakan pemeriksaan, hanya sebatas pada pemeriksaan ulang, pemeriksaan tambahan, dan pengambilalihan pemeriksaan. Sikap hukum KKRI tersebut tertuang di dalam Peraturan Komisi Kejaksaan RI Nomor 05/KK/04/12 tentang Tata Cara Penganganan Laporan Pengaduan Masyarakat (Per-KK Nomor 05/ KK/04/12). Pasal 1 butir 14 Per-KK Nomor 05/KK/04/12 menyatakan Pemeriksaan adalah Pemeriksaan Ulang, Pemeriksaan Tambahan atau Pengambilalihan Pemeriksaan, merupakan serangkaian kegiatan untuk mengungkapkan ada atau tidaknya pelanggaran terkait kinerja, kode perilaku jaksa, peraturan disiplin pegawai dan/atau peraturan perundang-undangan lainnya.

Ketentuan Pasal 1 butir 14 Per-KK No. 05/KK/04/12 jo Pasal 2 huruf a dan Pasal 2 huruf b Nota Kesepahaman Nomor tersebut memunculkan pertanyaan yang bersinggungan dengan penulisan ini, yakni apakah Perpres No. 18 Tahun 2011 memberikan wewenang kepada KKRI untuk melakukan pemeriksaan, pengusutan, dan penilaian sebagai bentuk tindak lanjut lapdumas di luar konteks pemeriksaan ulang, pemeriksaan tambahan, dan pengambilalihan pemeriksaan karena pengaturannya tidak dimuat secara tekstual. Penulis berpendapat, pertama, nomenklatur pemeriksaan pada Pasal 1 butir 14 Per-KK Nomor 05/KK/04/12 jo Pasal 2 huruf a dan Pasal 2 huruf b Nota Kesepahaman Nomor NK001/KK/05/2011 yang membatasi pemeriksaan hanya pada pemeriksaan ulang, pemeriksaan tambahan, dan pengambilalihan pemeriksaan merupakan penafsiran yang tidak sejalan dengan ide progresif sebagaimana dimaksud dari tulisan ini.

Sebaliknya, penulis berpendapat KKRI berwenang melakukan pemeriksaan karena dua alasan penting yang mendasarinya. Alasan pertama, yaitu penggalian hukum melalui penalaran terhadap ketentuan perundangundangan dalam hal ini terhadap PP No. 20 Tahun 2008 memberikan arah berpikir logis bahwa dalam rangka tugas pengawasan seyogyanya tercakup perangkat pengawasan 
fungsional. Walaupun PP No. 20 Tahun 2008 tidak mengatur pengawasan fungsional oleh KKRI, namun bersandar kepada penggalian hukum, tugas pengawasan PP No. 20 Tahun 2008 dapat menjadi acuan karena terkait bidang objek yang sama yakni pengawasan. Alasan kedua, yaitu secara tekstual Pasal 3 dan 4 Perpres No. 18 Tahun 2011 menyatakan bahwa dalam menjalankan tugas dan wewenang, KKRI dapat menyampaikan rekomendasi berupa pemberian sanksi terhadap jaksa dan pegawai tata usaha sesuai dengan pelanggaran yang dilakukan sebagaimana dimaksud dalam PP No. 53 Tahun 2010, Kode Etik dan Perundang-undangan. ${ }^{57}$ Rekomendasi KKRI yang dibuat tanpa perangkat fungsional ibarat berjalan dengan mata tertutup, sehingga sulit mencapai tujuan. Oleh karena itu, pelaksanaan tugas pengawasan terkait kewenangan menindaklanjuti sebuah lapdumas mutlak harus menggunakan perangkatnya. Pengawasan pada tindak lanjut lapdumas tersebut dikenal dengan pengawasan fungsional di dalam PP No. 20 Tahun 2008.

Berkaitan dengan persoalan tidak adanya pengaturan hukum acara secara tertulis perihal tindak lanjut lapdumas dalam Perpres No. 18 Tahun 2011, penulis berpendapat hal itu disebabkan perpres a quo menghadapkan KKRI pada dua pilihan sikap untuk menjalankan diskresi. Kedua pilihan tersebut, yaitu menindaklanjuti lapdumas dengan menggunakan perangkat fungsional $\mathrm{KKRI}^{58}$ atau meneruskan lapdumas tersebut kepada Jaksa Agung yang tindak lanjutnya akan diserahkan kepada aparat pengawasan internal. ${ }^{59}$

Oleh karena itu, lapdumas yang diajukan kepada KKRI dan diputuskan melalui rapat pleno yang hasilnya diteruskan kepada Jaksa Agung tidak dapat dipandang sebagai bagian dari upaya tindak lanjut yang dilaksanakan oleh KKRI. Menurut terminologi penulisan ini, penafsiran KKRI menindaklanjuti lapdumas hanya sebatas apabila hasil rapat pleno telah memutuskan rekomendasi terhadap suatu

\footnotetext{
$57 \quad$ Pasal 9 butir c Perpres Nomor 18 Tahun 2011.

$58 \quad$ Pasal 4 butir a Perpres Nomor 18 Tahun 2011.

$59 \quad$ Pasal 4 butir b Perpres Nomor 18 Tahun 2011.
}

lapdumas akan dilakukan tindak lanjut dengan melakukan pemeriksaan dan/atau inspeksi kasus, hingga keluarnya rekomendasi KKRI terhadap tindak lanjut yang telah dilakukan.

Sebenarnya, KKRI telah menjabarkan makna tindak lanjut dalam ketentuan Pasal 10 ayat (9) huruf a 19 Per-KK Nomor 05/KK/04/12 yang berbunyi "rekomendasi tindak lanjut" berupa inspeksi kasus atau pemeriksaan yang bertujuan untuk mengungkap ada tidaknya pelanggaran terkait kinerja, kode etik dan perilaku terlapor. ${ }^{60}$ Namun, adanya ketentuan Pasal 1 butir 14 Per-KK Nomor 05/KK/04/12 mengakibatkan pengaturan mengenai tindak lanjut dalam tata kerja Komisi Kejaksaan mengenai penanganan lapdumas menjadi tidak koheren. Oleh karena itu, ketentuan Pasal 1 butir 14 Per-KK 05/KK/04/12 direvisi berdasarkan rapat pleno Komisi Kejaksaan RI periode 2019-2023 ke-32 tanggal 20 Juli 2020, sehingga berbunyi "Pemeriksaan merupakan serangkaian kegiatan untuk mengungkap ada atau tidaknya pelanggaran terkait kinerja, kode perilaku jaksa, peraturan disiplin pegawai dan/ atau peraturan perundang-undangan lainnya."

Adanya perubahan tata kerja di Komisi Kejaksaan menyangkut penanganan lapdumas tersebut membawa perubahan yang signifikan terhadap eksistensi dan keberadaan KKRI di tengah-tengah masyarakat, untuk menjadi penyeimbang atas kekuasaan negara di bidang penuntutan oleh Kejaksaan RI. Penerapan hukum secara progresif terkait kewenangan untuk melakukan tindak lanjut lapdumas dalam kasus-kasus yang menjadi sorotan masyarakat, seperti kasus penganiayaan terhadap Novel Baswedan. Lapdumas yang teregister di Komisi Kejaksaan dengan Nomor 5745-0372 tersebut pada pokoknya melaporkan tentang kejanggalan dalam proses penuntutan oleh jaksa penuntut umum termasuk tuntutan 1 (satu) tahun kepada dua terdakwa yang dianggap terlalu ringan.

KKRI melakukan serangkaian kegiatan untuk mengungkapkan ada atau tidaknya

\footnotetext{
60 Pasal 10 ayat (9) butir a jo. 18 Peraturan Komisi Kejaksaan RI Nomor 05/KK/04/12.
} 
pelanggaran terkait kinerja, kode perilaku jaksa, peraturan disiplin pegawai dan/atau peraturan perundang-undangan lainnya, antara lain, dengan melakukan langkah nyata, mulai dari proses pemantauan, pengumpulan data dan bahan keterangan, proses pemeriksaan terhadap tujuh orang tim jaksa penuntut umum dari Kejaksaan Tinggi DKI dan Kejaksaan Negeri Jakarta Utara pada 23 Juli 2020. KKRI juga mengundang pejabat struktural pada Kejaksaan Tinggi DKI, yang dimulai dari Asisten Tindak Pidana Umum dan Kepala Kejaksaan Tinggi DKI serta Direktur Keamanan Negara Ketertiban Umum dan Tindak Pidana Umum Lainnya Kejaksaan Agung, untuk dimintai penjelasan, meskipun yang bersangkutan tidak hadir memenuhi panggilan.

Untuk perkara menarik perhatian publik lainnya, KKRI memosisikan diri sebagai garda terdepan dalam hal pengawasan dengan melakukan tindak lanjut berdasarkan kewenangan Pasal 4a Perpres No. 18 Tahun 2011 Lapdumas Nomor 102/MAKI/VII/2020 yang dilayangkan oleh Masyarakat Anti Korupsi Indonesia (MAKI). Salah satu perkara yang menarik perhatian publik, yaitu adanya dugaan pelanggaran kode etik oknum jaksa terkait pertemuannya dengan buronan dalam perkara korupsi hak tagih Bank Bali, Djoko Soegiarto Tjandra. Dalam rangka menindaklanjuti lapdumas a quo, KKRI melakukan rangkaian kegiatan pemeriksaan, pengusutan, antara lain, dengan melakukan panggilan terhadap oknum jaksa tersebut berdasarkan surat Ketua Komisi Kejaksaan Nomor B-115/KK/7/2020 tertanggal 27 Julis 2020 dan Surat Ketua Komisi Kejaksaan Nomor 135/KK/7/2020 tertanggal 30 Juli 2020 perihal pemanggilan Jaksa Dr. Pinangki Sirna Malasari, S.H., M.H untuk diperiksa terkait keterlibatannya dalam perkara a quo. Atas pemanggilan tersebut, yang bersangkutan tidak hadir tanpa memberikan alasan.

Selanjutnya, KKRI bersurat kepada Jaksa Agung Muda Pembinaan melalui Surat Ketua Komisi Kejaksaan RI Nomor B-382/C/ Cp.3/08/2020 tanggal 30 Juli 2020 perihal Bantuan Menghadirkan Dr. Pinangki Sirna
Malasari, S.H., M.H. Namun, atas surat tersebut Kejaksaan Agung menjawab melalui Surat Plt. Jaksa Agung Muda Pengawasan Nomor B-99/H/H.V/07/2020 tanggal $30 \mathrm{Juli}$ 2020 menyampaikan bahwa bidang pengawasan telah melaksanakan inspeksi kasus terhadap Dr. Pinangki Sirna Malasari dan hasilnya ditemukan ada pelanggaran disiplin sehingga yang bersangkutan dijatuhi hukuman disiplin tingkat berat berupa pembebasan dari jabatan struktural, dan selanjutnya bidang pengawasan akan berkoordinasi dengan Komisi Kejaksaan sekaligus memberitahukan hasil pemeriksaan.

Rangkaian kegiatan untuk mengusut ada atau tidaknya pelanggaran terkait kode etik maupun peraturan perundang-undangan dalam kasus pertemuan jaksa dan Djoko Soegiarto Tjandra, serta lapdumas terkait kejanggalan dalam proses penuntutan perkara penganiayaan Novel Baswedan yang dilakukan secara langsung oleh KKRI didasarkan kepada adanya kekhawatiran terjadinya resistensi apabila perkara tersebut ditangani oleh pengawas internal kejaksaan. Upaya itu juga dilakukan dalam rangka mengakomodasi tuntutan publik yang menginginkan proses pemeriksaan tersebut berjalan secara lebih transparan dan akuntabel. Upaya-upaya pengembanan amanah oleh KKRI untuk berdiri pada garda terdepan telah dilakukan secara optimal, terlepas di dalam pelaksanaannya ada ketidakpatuhan. Hal tersebut menjadi bahan evaluasi terkait pentingnya penguatan kembali KKRI secara kelembagaan, sehingga produk rekomendasi yang dihasilkan oleh KKRI lebih optimal.

Upaya yang dilakukan oleh KKRI dalam penanganan lapdumas yang menjadi sorotan publik tersebut merupakan langkah nyata dalam hal menjalankan kewenangan sebagaimana diatur di dalam Pasal 4 huruf a Perpres Nomor 18 Tahun 2011. Tanpa berpikir panjang tentang teks yang tertuang secara pasti serta sikap yang dipandang menyimpangi nota kesepahaman bersama, langkah tersebut mencerminkan sikap progresif yang secara nyata terwujud melalui perilaku (behavior) para pelaku hukum yang duduk di lembaga KKRI. Tindakan itu 
sendiri berpijak kepada nilai dan cita hukum pembentukan KKRI. Bahkan, di dalam tugas dan kewenangan KKRI menindaklanjuti lapdumas, dengan melakukan pemeriksaan dan inspeksi kasus, pengusutan, penilaian, dan rekomendasi secara tuntas tidak dibatasi pada kasus-kasus yang menjadi perhatian publik semata-mata. Lebih dari itu, KKRI dapat menangani lapdumas yang memiliki resistensi apabila ditangani oleh pengawas internal, serta kasus-kasus yang memiliki kelayakan dari sisi kategori lainnya.

Penjabaran terhadap tindak lanjut lapdumas tersebut juga selaras dengan penggalian hukum berkenaan dengan interpretasi teleologis. Berdasarkan interpretasi teleologis, pengembanan tugas dan kewenangan menindaklanjuti lapdumas yang disampaikan kepada KKRI seyogyanya tetap memperhatikan alasan-alasan yang menjadi dasar tentang pembentukan lembaga KKRI. Seperti telah diuraikan, munculnya lembagalembaga negara baru adalah hasil reformasi di bidang hukum melalui penataan kembali sistem ketatanegaraan, dalam rangka mewujudkan kehidupan bermasyarakat, berbangsa, dan bernegara sesuai dengan asas negara hukum dan asas negara demokrasi.

Salah satu bentuk reformasi dalam lingkup penegakan hukum dilakukan melalui pembentukan lembaga pengawas eksternal yang memiliki tujuan untuk meningkatkan profesionalitas, integritas, dan akuntabilitas pada institusi penegak hukum maupun di lini aparatnya. Pembentukan lembaga pengawas eksternal pada Kejaksaan RI merupakan dampak dari adanya reformasi penegakan hukum. Pembentukan KKRI secara lebih spesifik diutarakan oleh Masyarakat Pemantau Peradilan Indonesia Fakultas Hukum Universitas Indonesia (MaPPI FHUI) dikarenakan minimnya efektifitas kelembagaan internal kejaksaandan tingginya semangat membela korps. ${ }^{61}$ Namun terlepas dari hal itu, lembaga pengawas eksternal tentunya adalah

${ }_{61}$ Coky R. Ramadhan, "Kedudukan, Tugas, dan ... ", Teropong, Vol. 1, November 2013, hal. 5. konsep ideal yang diharapkan dapat berfungsi sesuai konsep checks and balances terhadap penyelenggaraan kekuasaan yang dijalankan oleh pihak kejaksaan.

Berdasarkan diskursus tersebut, argumentasinya menjadi tidak tepat apabila KKRI yang dilahirkan untuk menguatkan sistem pengawasan pada lembaga kejaksaan, tidak memiliki kewenangan untuk melakukan tindak lanjut secara langsung. Ketidaktepatan tersebut terjadi karena KKRI tidak dilekati dengan kewenangan untuk melakukan pemeriksaan dan inspeksi kasus sebagai bagian dari tugasnya untuk menindaklanjuti laporan pengaduan masyarakat yang disampaikan kepadanya, sebagai akibat tidak adanya ketentuan secara tekstual di dalam Perpres No. 18 Tahun 2011. Pemeriksaan yang sebatas pada pemeriksaan ulang, pemeriksaan tambahan, dan pengambilalihan pemeriksaan tidak memberikan ruang gerak yang luas bagi KKRI dalam menjalankan tugasnya. Ini akan kontradiktif apabila KKRI harus berdiri pada garda terdepan pengawasan di dalam suatu kondisi tertentu, karena ada kemungkinan terjadinya resistensi terhadap suatu Lapdumas apabila ditangani oleh pengawas internal. Selain itu, ada persoalan psikologis terhadap penanganan suatu Lapdumas untuk kasuskasus yang menjadi sorotan publik serta kasus lainnya yang menuntut KKRI untuk berdiri di garda terdepan tugas pengawasan. Beberapa hal tersebut tidak mungkin dapat menjawab persoalan, apabila KKRI dipandang tidak memiliki kewenangan untuk melakukan pengawasan dalam konteks menindaklanjuti suatu Lapdumas.

Di dalam mengimplementasikan tugastugas secara keseluruhan, tindak lanjut terhadap Lapdumas memang tidak harus dilakukan secara langsung oleh KKRI, tetapi melalui opsi Pasal 4 huruf b Perpres No. 18 Tahun 2011. Adapun pertimbangannya adalah pentingnya sinergitas kelembagaan serta faktor efektifitas dan efisiensi dalam pelaksanaan tugas pengawasan. Namun, tidak dilupakan bahwa semangat progresif dalam pengembanan 
tugas dan kewenangan sesuai Perpres No. 18 Tahun 2011, harus dimaknai memberikan kewenangan kepada KKRI untuk melakukan langkah-langkah secara langsung untuk melakukan tindakan lebih lanjut terhadap Lapdumas sebagai bentuk bagian dari tugas pengawasan oleh KKRI. Dengan memiliki cara pandang yang jernih terhadap apa yang menjadi tugas dan kewenangannya, diharapkan dapat tercapai kinerja optimal dalam pengembanan tugas pengawasan oleh KKRI.

\section{Penutup}

\section{A. Simpulan}

Fungsi Pengawasan oleh KKRI terhadap institusi Kejaksaan RI hakikatnya merupakan penjabaran dari asas negara hukum dan asas negara demokrasi melalui penguatan sistem mekanisme checks and balances. Salah satu tugas dan kewenangan KKRI di bidang pengawasan berdasarkan Perpres No. 18 Tahun 2011, yaitu menindaklanjuti lapdumas tentang kinerja dan perilaku jaksa dan pegawai kejaksaan dalam menjalankan tugas dan wewenangnya, baik di dalam maupun di luar kedinasan. Kewenangan tersebut dari perpektif hukum progresif pada hakikatnya merupakan bagian dari tugas pengawasan oleh perangkat pengawasan KKRI melalui serangkaian tindakan nyata sejak diterimanya lapdumas, penelahaan administrasi dan substansi, pengumpulan data dan bahan keterangan yang diperlukan, inspeksi kasus yang meliputi permintaan penjelasan dan pemeriksaan terhadap terlapor, serta tindakan lainnya. Kewenangan KKRI tersebut bertujuan untuk mengungkap ada tidaknya pelanggaran terkait kinerja, kode etik dan perilaku maupun perundang-undangan aparat internal kejaksaan, yang hasilnya akan dituangkan ke dalam bentuk rekomendasi KKRI. Berdasarkan hal itu, sesungguhnya KKRI berwenang melakukan tindak lanjut lapdumas atas perilaku dan kinerja jaksa dan pegawai kejaksaan, meskipun pengaturan pemeriksaan secara tekstual di dalam Perpres No. 18 Tahun 2011 hanya sebatas pada pemeriksaan ulang, pemeriksaan tambahan, dan pengambilalihan pemeriksaan.

\section{B. Saran}

Kewenangan tindak lanjut lapdumas perlu diatur secara tegas di dalam Perpres No. 18 Tahun 2011 sebagai penguatan bagi KKRI dalam menjalankan tugas pengawasan serta kewenangan penjatuhan sanksi, apabila terjadi ketidakpatuhan terhadap pengembanan tugas KKRI dalam menindaklanjuti lapdumas. Pada tataran operasional, diperlukan penyamaan persepsi antara KKRI dengan Kejaksaan RI sebagai lembaga yang mengemban tugas pengawasan agar tercipta keselarasan dan sinergitas dalam menjalankan tugasnya. Penyamaan persepsi itu dimulai dari tahapan peninjauan ulang Nota Kesepahaman Jaksa Agung RI dengan Ketua KKRI Nomor Kep-009/A/JA/05/2011 dan Nomor NK-001/KK/05/2011 tentang Mekanisme Kerja Antara Kejaksaan RI dengan Komisi Kejaksaan RI dalam Melaksanakan Pengawasan, Pemantauan dan Penilaian atas Kinerja dan Perilaku Jaksa dan Pegawai Kejaksaan.

\section{Daftar Pustaka}

Jurnal

Christianto, Hwian. "Penafsiran Hukum Progresif Dalam Perkara Pidana". Mimbar Hukum. Vol. 23. No. 3. Oktober 2011.

Hastuti, Sri dan Lasmaida Limbong. "Pengukuran Kepuasan Masyarakat Terhadap Kinerja Kejaksaan Dalam Penanganan Perkara." Jurnal Bina Adhyaksa. Vol. 6. Edisi 3. Juli 2016.

Hairi, Prianter Jaya. "Judicial Review PasalPasal Makar KUHP: Perspektif Penafsiran Hukum dan HAM". Negara Hukum. Vol. 8. No. 2. November 2017.

Irawan, Benny Bambang. "Perkembangan Demokrasi di Indonesia”. Jurnal Hukum dan Dinamika Masyarakat. Vol. 5. No. 1. Oktober 2007.

M. Nihaya. "Demokrasi dan Problematikanya di Indonesia”. Jurnal Sulesana. Vol. 6. 2011. 
Mazjah, R. Muhamad Ibnu. "Kedudukan dan Fungsi Dewan Pers dalam Tatanan Negara Hukum dan Negara Demokrasi”. Prodigy. Vol. 7. No.2. Desember 2019.

Nursyariffah. "Menuju Efektifitas Kewenangan Komisi Kejaksaan”. Teropong, Vol. 1, November 2013.

Ramadhan, Coky R. "Kedudukan, Tugas, dan Kewenangan Komisi Kejaksaan”. Teropong. Vol. 1. November 2013.

Simamora, Janpatar. "Analisa Yuridis Terhadap Model Kewenangan Judicial Review di Indonesia." Hasil Penelitian. Lembaga Penelitian Universitas HKBP Nommensen, Medan, 2012.

Sunarto, "Prinsip Check And Balance Dalam

Sistem Ketatanegaraan Indonesia", Jurnal Masalah-Masalah Hukum, Vol. 45, No. 2, 2016.

Sutriyanti."Tinjauan Yuridis terhadapKewenangan Majelis Permusyawaratan Rakyat Republik Indonesia (MPR) dalam Wacana Menetapkan Kembali Pokok-Pokok Haluan Negara". Prodigy. Vol. 7. No. 2. Desember 2019.

Triwahyuni, Ajeng. "Strategi Penguatan Komisi Kejaksaan dalam Mendorong Pencegahan dan Pemberantasan Korupsi”. Teropong. Volume 1. 2013.

\section{Buku}

Asshiddiqie, Jimly. Hukum Tata Negara dan PilarPilar Demokrasi. Jakarta: Konstitusi Pers. 2004.

_. Menuju Negara Hukum Yang Demokratis. Jakarta: Buana Ilmu Populer. 2008.

. Pengantar Ilmu Hukum Tata Negara. Jakarta: Raja Grafindo Persada. 2013.

Effendy, Marwan. Kejaksaan Posisi dan Fungsinya Dari Perspektif Hukum. Jakarta: Gramedia Pustaka Utama. 2005.

Hamzah, Andi. Perlindungan Hak-Hak Asasi Manusia Dalam Hukum Acara Pidana. Jakarta: Universitas Trisakti. 2010.

Mahfud M.D. Moh. Politik Hukum di Indonesia. Jakarta: Rajawali Pers. 2011.
Marzuki, Peter Mahmud. Penelitian Hukum. Jakarta: Prenadamedia. 2011.

Mas'udi, Masdar F. "Ombudsman Melawan Positivisme Hukum demi Good Governance dan Keadilan”. Artikel dalam Peranan Ombudsman Dalam Pemberantasan Dan Pencegahan Korupsi Serta Pelaksanaan Pemerintahan yang Baik. Jakarta: Komisi Ombudsman Nasional. 2005

Moeljatno. Asas-Asas Hukum Pidana. Jakarta: Rineka Cipta. 2017.

Nitibaskara, Ronny Rahman. Tegakkan Hukum Gunakan Hukum. Jakarta: Kompas. 2007.

Rahardjo, Satjipto. Hukum Progresif Sebuah Sintesa Hukum Indonesia. Yogyakarta: Genta Publishing. 2009.

. Penegakan Hukum Progresif. Jakarta: Kompas. 2010.

Ridwan, Juniarso dan Achmad Sodik Sudradjat. Hukum Administrasi Negara dan Kebijakan Pelayanan Publik. Bandung: Nuansa. 2012.

Sujata, Antonius et all. Ombudsman Indonesia Masa Lalu, Sekarang dan Mendatang. Jakarta: Komisi Ombudsman Nasional. 2002.

Tanya, Bernard L. et. al. Teori Hukum Strategi Tertib Manusia Lintas Ruang dan Generasi, Yogyakarta: Genta Publising. 2010.

\section{Pustaka dalam Jaringan}

CNN Indonesia. 6 Januari 2020, "Ambil Getah Karet Senilai Rp17 Ribu, Samirin Dibui 2 Bulan", https://www.cnnindonesia.com/na sional/20200116141042-12-465939/ ambilgetah-karet-senilairp17 ribu-samirin-dibui2-bulan, diakses tanggal 1 April 2020.

Kamus Besar Bahasa Indonesia, arti kata "Tindak Lanjut", https://kbbi.web.id/tindak \%20lanjut, diakses tanggal 9 Maret 2020.

Santosa, Mas Achmad Santosa, "Komisi Kejaksaan”, Majalah Tempo. https://majalah. tempo.co/read/kolom/105299/komisikejaksaan?hidden $=$ login, diakses tanggal 9 Maret 2020. 